\title{
PENGARUH STRATEGI PEMBELAJARAN CRITICAL INCIDENT BERBANTUAN GAMBAR SERI TERHADAP KETERAMPILAN MENULIS MAHASISWA PADA MATAKULIAH ENGLISH FOR JURNALISM PROGRAM STUDI BAHASA INGGRIS UMSU
}

\author{
Dewi Juni Artha dan Ratna Sari Dewi \\ Universitas Muhammadiyah Sumatera Utara \\ dewijuniartha@umsu.ac.id
}

\begin{abstract}
Abstrak. Tujuan penelitian ini adalah (1) Untuk mengetahui apakah ada Pengaruh Strategi Pembelajaran Critical Incident Berbantuan Gambar Seri Terhadap Kemampuan Menulis Mahasiswa Pada Mata Kuliah English for Journalism Program Studi Bahasa Inggris FKIP UMSU T.A 2017/2018. (2) Untuk mengetahui berapa persen ada Pengaruh Strategi Pembelajaran Critical Incident Berbantuan Gambar Seri Terhadap Kemampuan Menulis Mahasiswa Pada Mata Kuliah English for Journalism Program Studi Bahasa Inggris FKIP UMSU. Penelitian ini merupakan penelitian eksperimental. .Teknik pelaksanaan program untuk penelitian ini adalah (1) tes awal digunakan untuk mengukur kemampuan awal siswa terhadap materi yang diajarkan (2) sedangkan tes akhir dilakukan untuk mengetahui hasil belajar siswa setelah diberikan perlakuan oleh guru dengan menggunakan Strategi Pembelajaran Critical Incident.
\end{abstract}

Kata Kunci: Strategi Pembelajaran Critical Incident, Keterampilan Menulis

\begin{abstract}
The purposes of this study are (1) To find out whether there is an effect of Critical Incident Learning Assisted by Picture Series toward student writing Skill in English for Journalism at English Studied Program FKIP of UMSU Academic Year 2017/2018. (2) To find out what percentages the effect of Critical Incident Learning Strategy assisted by Pictures Series on Student Writing Skill in English for Journalism at English Studied Program FKIP UMSU. This research is an experimental research. The techniques for this research are (1) the post test is used to measure students' former ability to the material being taught (2) while the final test is carried out to find out the student learning outcomes after being given treatment by the teacher using the Critical Incident Learning Strategy.
\end{abstract}

Keywords: Critical Incident Learning Strategies, Writing Skills

\section{PENDAHULUAN}

Kehidupan manusia tidak dapat lepas dari kegiatan berbahasa. Bahasa merupakan sarana untuk berkomunikasi antar manusia. Bahasa sebagai alat komunikasi ini, dalam rangka memenuhi sifat manusia sebagai makhluk sosial yang perlu berinteraksi dengan sesama manusia. Bahasa dianggap sebagai alat yang paling sempurna dan mampu membawakan pikiran.

Keterampilan berbahasa terdiri dari empat aspek, yaitu menyimak atau mendengarkan, berbicara, membaca, dan menulis. Mahasiswa harus menguasai keempat aspek tersebut agar terampil berbahasa. Dengan demikian, pembelajaran keterampilan berbahasa di kampus tidak hanya menekankan pada teori saja, tetapi mahasiswa dituntut untuk mampu menggunakan bahasa sebagaimana fungsinya, yaitu sebagai alat untuk berkomunikasi.

Menulis adalah keterampilan produktif dengan menggunakan tulisan. Menulis dapat dikatakan suatu keterampilan berbahasa yang paling rumit di antara jenis-jenis keterampilan berbahasa lainnya. Ini karena menulis bukanlah sekedar menyalin kata-kata dan kalimat-kalimat, melainkan juga mengembangkan dan menuangkan pikiran-pikiran dalam suatu struktur tulisan yang teratur. 
Dalam menulis, biasanya seseorang menggunakan kata-kata yang dikenal dan telah dipahami makna maupun tujuan penulisannya. Akan tetapi banyak materi yang telah dikuasai oleh seseorang yang tidak pernah muncul dalam tulisannya. Hal ini disebabkan karena untuk menggunakan suatu kata dalam tulisan diperlukan pengetahuan yang lebih mendalam dalam hal penerapan kata tersebut.

Sri Hastuti (dalam Saddhono, 2012:97) menyatakan bahwa kegiatan menulis merupakan kegiatan yang sangat kompleks karena melibatkan cara berpikir yang teratur dan berbagai persyaratan yang berkaitan dengan teknik penulisan, antara lain (1) adanya kesatuan gagasan, (2) penggunaan kalimat yang jelas dan efektif, (3) paragraf disusun dengan baik, (4) penerapan kaedah ejaan yang benar, dan (5) penguasaan kosakata yang memadai. Sebelum meningkatkan keterampilan menulis di kalangan pelajar, perlu diketahui faktor penyebab menurunnya kemampuan menulis, di antaranya:

a) Faktor Internal (dari dalam) yaitu faktor yang berasal dari diri kita sendiri atau timbul secara spontan dari hati nurani kita.

Macam-macam faktor internal yang mempengaruhi keterampilan menulis yaitu:

a. Kurangnya minat menulis para pelajar

b. Kesulitan menuangkan ide

c. Malas membaca, jika seseorang sudah tidak tertarik untuk membaca maka sulit

b) Faktor Eksternal (dari luar) yaitu faktor yang berasal dari luar atau lingkungan sekitar.

Jurnalisme ialah sebuah kegiatan atau proses mengumpulkan, mengolah, dan menyebarkan informasi melalui media massa kepada khalayak.

Ada lima cakupan jurnalisme, yakni:

1. Menulis

2. Wawancara

3. Fotografi

4. Reportase

5. Menganalisis fenomena dan peristiwa
Penguasaan terhadap keterampilan menulis (ilmu jurnalistik) sangat penting bagi mahasiswa dan juga pelajar. Sebab, dalam perjalanannya, ilmu jurnalistik tidak bisa dilepaskan dari aktivitas menulis dan menjadi instrumen penting bagi kegiatan belajar mengajar.

Pembelajaran pada dasarnya merupakan upaya untuk mengarahkan anak didik ke dalam proses belajar sehingga mereka dapat memperoleh tujuan belajar sesuai dengan apa yang diharapkan. Pembelajaran hendaknya memperhatikan kondisi individu anak karena merekalah yang akan belajar.

Mahasiswa tentu dituntut menguasai jurnalistik, karena dalam setiap pertemuan perkualiahan, tugas, makalah selalu menyertai. Banyaknya tugas-tugas dalam aktivitas belajar mengajar yang mensyaratkan pernguasaan kemampuan menulis yang baik, ilmu jurnalistik mestinya tidak bisa dipisahkan dalam keseharian mereka.

Kemampuan menulis (jurnalistik) ini sangat bermanfaat bagi pelajar dan mahasiswa dalam menuangkan pemikiran. Manfaat ini akan semakin terasa saat pelajar dan mahasiswa membuat tugas makalah, apalagi bagi mahasiswa yang sedang menulis skripsi.

Mata kuliah Jurnalisme bertujuan agar peserta didik mampu/ memiliki keterampilan menulis, menuangkan ide, gagasan, informasi, berita, data maupun fakta ke dalam sebuah tulisan. Namun, mata kuliah ini dianggap sebagai matakuliah yang membosankan. Mahasiswa belum sepenuhnya menunjukkan minat terhadap mata kuliah ini. Hal ini disebabkan karena menulis termasuk aspek kegiatan berbahasa yang dianggap sulit. Hal itu dikeluhkan oleh banyak orang. Peserta didik di pendidikan dasar dan menengah, mahasiswa di pendidikan tinggi, dan bahkan orangorang yang sudah menamatkan perguruan tinggi pun mengeluhkan sulitnya menulis. Akibat keluhan itu akhirnya menjadi opini umum, bahwa menulis itu memang sulit.

Kemampuan menulis diperlukan di semua lapangan pekerjaan. Misalnya 
seorang dokter perlu menuliskan resep obat bagi pasiennya. Seorang polisi perlu menuliskan detil suatu insiden berupa sebuah laporan penyelidikan atau introgasi untuk digunakan dalam persidangan. Seorang sekretaris perlu menuliskan surat atau laporan untuk disimpulkan kepada pemimpin perusahaan. Seorang direktur perlu menuliskan memori, hasil evaluasi, atau instruksi. Seorang kontraktor perlu menuliskan suatu perincian dana pembangunan sebuah pekerjaan secara lengkap dan teliti agar mendapatkan kesempatan memenangkan suatu tender proyek. Sampai munculnya pendapat bahwa keberhasilan suatu jabatan atau pekerjaan ditenttukan oleh kemampuan yang bersangkutan berkomunikasi secara efektif, khususnya komunikasi tulis.

Berdasarkan penjelasan tersebut maka penulis membuat sebuah penelitian yang berjudul Pengaruh Strategi Pembelajaran Critical Incident Berbantuan Gambar Seri Terhadap Keterampilan Menulis Mahasiswa Pada Matakuliah English For Jurnalism Program Studi Bahasa Inggris UMSU

\section{METODE PENELITIAN}

\section{a. Jenis Penelitian}

Penelitian ini merupakan penelitian eksperimental. Penelitian ini dilakukan di FKIP UMSU Jalan. Kapten Mukhtar Basri No. 3 Medan. Waktu penelitian dilaksanakan pada semester genap tahun pelajaran 2017/2018 antara bulan Januari sampai dengan selesai. Populasi dalam penelitian ini adalah enam kelas jurusan Pendidikan Bahasa Inggris semester enam. Sedangkan yang menjadi sampel dalam penelitian ini adalah dua kelas yaitu kelas A Pagi dan A Sore Prodi Pendidikan Bahasa Inggris Fakultas Keguruan dan Ilmu Pendidikan Universitas Muhammadiyah Sumatera Utara Tahun Ajaran 2017/2018.

\section{b. Instrumen Penelitian}

Instrumen penelitian adalah alat yang digunakan oleh peneliti untuk mengumpulkan data. Adapun yang menjadi instrumen penelitian adalah tes.

Dalam penelitian ini tes yang diberikan pada siswa bertujuan untuk mengetahui kemampuan keterampilan menulis mahasiswa. Tes yang diberikan berbentuk tes uraian. Adapun tes terdiri dari :

1. Tes Awal (pre-test)

Tes awal (pre-test) merupakan tes yang diberikan kepada mahasiswa sebelum diberikan strategi pada kedua kelas. Tes ini digunakan untuk mengukur kemampuan awal siswa terhadap keterampilan menulis mahasiswa.

2. Tes Akhir (post-test)

Tes akhir (post-test) merupakan tes yang diberikan kepada mahasiswa setelah dilakukan pembelajaran pada kedua kelas, dimana kelas control dosen masih menggunakan metode ceramah, sedangkan pada kelas eksperimen dosen sudah menggunakan strategi Critical Incident . Tes akhir bertujuan untuk melihat hasil keterampilan menulis mahasiswa dengan atau tanpa strategi Critical Incident.

\section{HASIL PENELITIAN DAN \\ PEMBAHASAN}

Deskripsi data yang disajikan dari hasil penelitian ini adalah untuk memberikan gambaran secara umum mengenai penyebaran data yang diperoleh di lapangan.

Penelitian ini dilakukan pada mahasiswa mata kuliah English for Journalism FKIP UMSU Tahun Akademik 2017/2018.

Berdasarkan judul dan rumusan masalah, penelitian ini terdiri dari dua variable yaitu data tentang strategi pembelajaran Critical Incident berbantuan gambar seri(X) terhadap Kemampuan Menulis (Y). Pengumpulan data dilakukan dengan cara memberikan pre-test dan post- test.

Dalam penelitian ini, pelaksanaan tes pertama (pre-test) bertujuan untuk mengetahui siswa dalam memahami materi tentang keterampilan menulis pada 
matakuliah English for Jurnalism. Sedangkan tes kedua (post-test) bertujuan untuk mengetahui pengaruh strategi pembelajaran Critical Incident berbantuan Gambar Seri terhadap kemampuan menulis pada matakuliah English for Journalism.

\section{Kegiatan Sebelum Sesudah Menggunakan Strategi Pembelajaran Critical Incident berbantuan Gambar Seri Pertemuan Pertama}

Kegiatan pembelajaran diawali dengan dosen memberikan salam (berdoa), mengkondisikan kelas dengan cara merapikan tempat duduk, mengamati tingkat kebersihan kelas, menanyakan kehadiran mahasiswa. Memotivasi mahasiswa dengan memberikan penjelasan tentnag tujuan pembelajaran yang ingin dicapai.

Selanjutnya dosen menjelaskan materi secara sederhana mengenai materi keterampilan menulis. Memberikan kesempatan kepada mahasiswa untuk berfikir dan menganalisa tentang materi dan bertanya. Selanjutnya, guru memberikan tugas pretes dan melakukan refleksi bersama-sama dan menutup pembelajaran dengan salam.

\section{Pertemuan II (Kedua)}

Pada pertemuan kedua, langkahlangkah yang dilakukan tidak jauh berbeda dengan pertemuan pertama, yaitu kegiatan pembelajaran diawali dengan cara merapikan tempat duduk, mengamati tingkat kebersihan kelas, menanyakan kehadiran mahasiswa. Memotivasi mahasiswa dengan memberikan penjelasan tentang tujuan pembelajaran yang ingin dicapai. Yang membedakan dengan pertemuan pertama adalah kegiatan ini menggunakan strategi pembelajaran Critical Incident berbantuan Gambar Seri. Tahap awal dosen membagi siswa ke dalam kelompok keterampilan menulis/ tehnik menulis yang baik. Kemudian dosen memberikan contoh cara menulis menggunakan bantuan gambar seri. Satu persatu perwakilan dari tiap-tiap kelompok maju ke depan kelas untuk memilih satu gambar seri secara acak. Lalu melalui gambar seri yang telah dipilih oleh perwakilan mahasiswa tersebut tiap kelompok diminta untuk menceritakan terlebih dahulu kira-kira apa yang akan mereka tuangkan dalam tulisan mereka nanti terkait dengan gambar tersebut. Dosen menampung seluruh ide yang mereka sampaikan. Setelah itu bersama-sama menyatukan ide. Tiap kelompok lalu menuliskan cerita atau wacana dalam bentuk paragraph yang tepat.

Setelah memberikan penjelasan dan contoh-contoh, dosen memberikan post-test kepada mahasiswa dan melakukan refleksi bersama-sama dan menutup pelajaran dengan mengucapkan salam.

Sebagai gambaran secara umum, mengenai distribusi data penelitian yang diperoleh di lapangan, maka data yang ada dideskripsikan berupa data yang telah diolah dari data mentah yang telah diperoleh dengan menggunakan bentuk analisa sebagai berikut:

\section{Pre-test}

Adapun hasil pre-test dalam penelitian ini dapat dilihat pada tabel di bawah ini:

Table 1

Data Nilai Ketuntasan Mahasiswa Pre-

\begin{tabular}{|l|l|l|l|}
\multicolumn{5}{|c}{ Test } \\
\begin{tabular}{|l|l|} 
Nil \\
ai
\end{tabular} & $\begin{array}{l}\text { Jumlah } \\
\text { Mahasis } \\
\text { wa }\end{array}$ & Presentasi & $\begin{array}{l}\text { Keteranga } \\
\mathrm{n}\end{array}$ \\
\hline $\begin{array}{l}\geq 7 \\
5\end{array}$ & 21 & $56,76 \%$ & $\begin{array}{l}\text { Tidak } \\
\text { Lulus }\end{array}$ \\
\hline $\begin{array}{l}<7 \\
5\end{array}$ & 16 & $43,24 \%$ & Lulus \\
\hline
\end{tabular}

Pada perhitungan hasil pre-test di atas, diperoleh hasil dari kemampuan menulis mahasiswa diklasifikasikan kedalam dua kategori, yaitu lulus dan tidak lulus. Adapun yang dikategorikan tidkak lulus berjumlah 21 mahasiswa dengan persentase $56,76 \%$, dan yang dikategorikan lulus berjumlah 16 orang mahasiswa dengan persentase $43,24 \%$. 
2. Post-test

Adapun hasil post-test dalam penelitian ini dapat dilihat pada table di bawah ini:

Tabel 2

Data Nilai Ketuntasan Siswa PostTest

\begin{tabular}{|l|l|l|l|}
\hline $\begin{array}{l}\text { Nila } \\
\text { i }\end{array}$ & $\begin{array}{l}\text { Jumla } \\
\text { h } \\
\text { Siswa }\end{array}$ & $\begin{array}{l}\text { Presenta } \\
\text { si }\end{array}$ & $\begin{array}{l}\text { Keteranga } \\
\mathrm{n}\end{array}$ \\
\hline$\geq 75$ & 5 & $13,51 \%$ & $\begin{array}{l}\text { Tidak } \\
\text { Lulus }\end{array}$ \\
\hline$<75$ & 32 & $86,49 \%$ & Lulus \\
\hline \multicolumn{4}{|c|}{ Pada perhitungan hasil }
\end{tabular}

post-test diatas, diperoleh hasil dari kemampuan menulis mahasiswa diklasifikasikan kedalam dua kategori, yaitu lulus dan tidak lulus. Adapun yang dikategorikan tidak lulus sebanyak 5 orang mahasiswa dengan persentase $13,51 \%$ dan yang dikategorikan lulus sebanyak 12 orang siswa dengan persentase $86,4 \%$.

\section{SIMPULAN}

Penelitian ini bertujuan untuk mengetahui pengaruh penerapan strategi critical incident terhadap kemampuan menulis mahasiswa pada masa kuliah English for Journalism. Setelah melalui proses penelitian dan berdasarkan analisis terhadap data - data yang ada, maka dapat disimpilkan beberapa hal yang merupakan inti dari hasil penelitian ini, sebagai berikut.

1. Dari hasil penelitian sebelum menggunakan strategi pembelajaran critical incident Berbentuk Gambar Seri diperoleh nilai rata - rata sebesar 69,21 dengan nilai tertinggi 92 dan nilai terendah 39 serta standart deviasi sebesar 14,47. Berdasarkan hal tersebut mahasiswa yang mencapai nilai Kriteria Ketentuan Minimum (KKM) berjumlah 21 orang mahasiswa dan yang belum mencapai KKM berjumlah 12 Orang mahasiswa.

2. Dari hasil penelitian sebelum menggunakan strategi pembelajaran Critical Incident Berbantuan Gambar Seri diperoleh nilai rata - rata sebesar 85,30 dengan standard deviasi sebesar 11,93. Berdasarkan hal tersebut siswa yang mencapai nilai Kriteria Ketentuan Minimum (KKM) berjumlah 32 Orang dan yang belum mencapai nilai KKM berjumlah 5 orang mahasiswa.

3. Berdasarkan uji hepotesis diperoleh $t_{\text {hitung }}$ sebesar 5,2757 pada araf signifikan $\alpha=0,05$ dan $\mathrm{dk}=\mathrm{n}-1=37$ $2=35$ dari daftar tabel distribusi $t_{\text {tabel }}$ $=1,68957$ hipotesis yang diterima $\mathbf{h}_{\mathrm{a}}$ yang dinyatakan adanya pengaruh strategi pembelajaran Critical Insident Berbantuan Gambar Seri terhadap keterampilan Menulis Mahasiswa Prodi Bahasa Inggris FKIP UMSU Tahun Akademik 2017/2018.

\section{SARAN}

1. Kemampuan siswa melulis cerpen berdasarkan pengalaman pribadi perlu ditingkatkan lagi. Hal tersebut tentunya memerlukan stategi pembelajaran yang lebih efektif dan menari yang digunakan dalam proses belajar mengajar di sekolah. Salah satu strategi pembelajaran yang dapat dijadikan alternative adalah stretegi Critical Incident .

2. Startegi critical incident memerlukan pemahaman guru bahsa dan sastra yang mendalam baik dari segi persiapan, pelaksanaan, sampai evaluasi agar hal yang diharapkan yakni peningkatan kemampuan menulis khususnya pada mata kuliah jurnalistik.

3. Diharapkan agar peneliti selanjutnya yang meneliti masalah yang sama diharapkan dapat meninjau lebih dahulu karakteristik siswa, sehingga dapat mempersiaplan stratrgi serta alat bantu lainnya yang lebih kreatif dan inovatif sesuai dengan materi dan masalah yang akan diteliti.

\section{DAFTAR PUSTAKA}

Al Rasyidin dan Wahyudin Nur Nasution. 2013. Teori Belajar dan Pembelajaran. Medan: Perdana Publishing.

Arikunto. 2013. Prosedur Penelitian suatu pendekatan praktik. Jakarta: Rineka Cipta.

Arsyad, Azhar. 1997. Media pembelajaran. Jakarta: Rajawali Pers

Aspia,Asrar. 2013. Media Pembelajaran. Medan : Perdana Publishing 
Bahri Djamarah, Syaiful. 2013. Strategi Belajar Mengajar. Jakarta: Rineka Cipta

Bungin, M. Burhan. 2008. Metodologi Penelitian Kuantitatif, Komunikasi, Ekonomi, dan Kebijakan Publik serta IlmuIlmu Sosial lainnya. Jakarta: Kencana

Dimyanti dan Mudjiono. 2006. Belajar dan pembelajaran. Jakarta: Rineka Cipta

Djuanda, Dadan. 2006. Pembelajaran Bahasa Indonesia yang Komunikatif dan Menyenangkan. Jakarta: Depdiknas

Hamalik, Oemar. 2010. Proses BelajarMengajar. Jakarta: BumiAksara

Mulyati, Yeti. 2000. Pendidikan Bahasa dan Sastra Indonesia di Kelas Tinggi. Jakarta: Universitas Terbuka. Muslich,

Masnur. 2007. KTSP Dasar Pemahaman dan Pengembangan. Jakarta: Bumi Aksara.

Saddhono, Kundharu. 2012. Meningkatkan Keterampilan Berbahasa Indonesia. Bandung: CV. Karya Putra Darwati.

Slameto, Belajar dan Faktor-faktor Yang Mempengaruhi. Jakarta: Rineka Cipta

Sudjana, H.D. 2005. Metoda \& Teknik Pembelajaran Partisipatif. Bandung: Falah Production.

Sugiyono. 2010. Metode Penelitian Pendidikan. Bandung: Alfa 